\author{
امكانسنجى سامانه اجراى آبيارى قطرهاى با توجه به كيفيت \\ آب زيرزمينى: مطالعه موردى دشت خرم آباد \\ ياسر سبزوارى و على حيدر نصرالهى

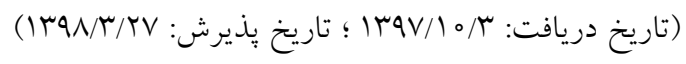

جكيده

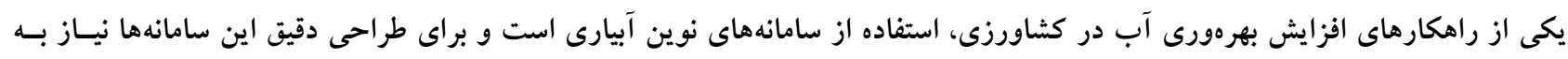

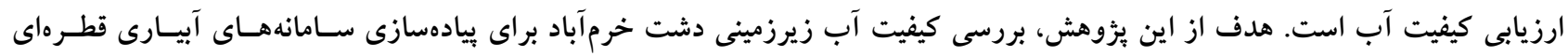

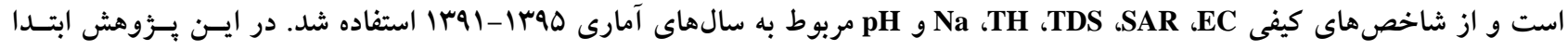

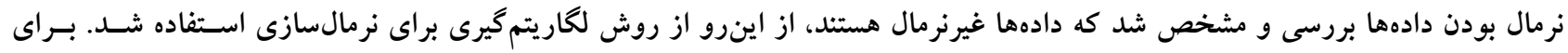

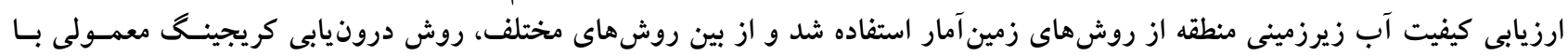

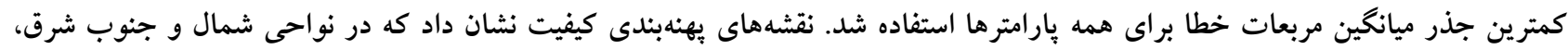

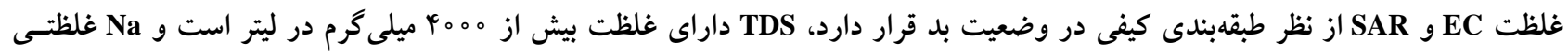

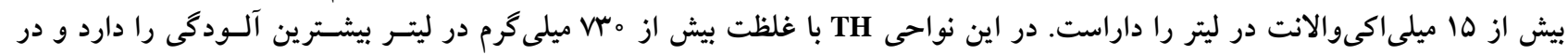

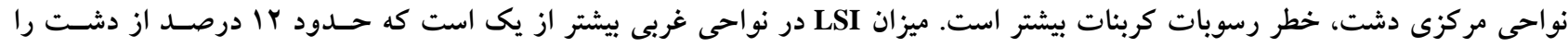

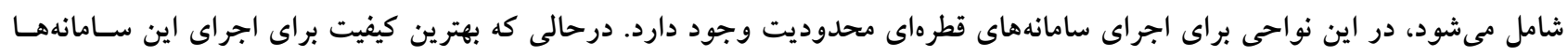

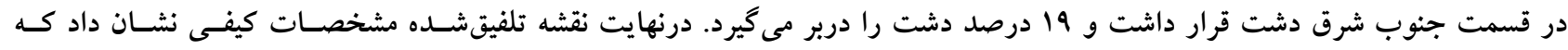

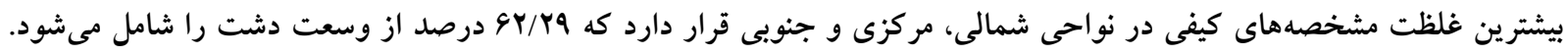

وازههاى كليدى: سامانهاى قطرهاى، گرفتحى قطرهجكان، شاخص اشباع لانزير، كيفيت آب زيرزمينى 


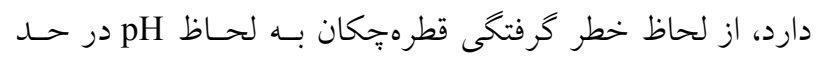

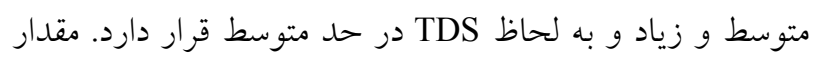

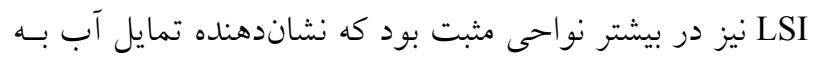

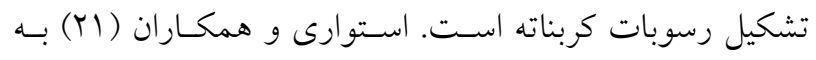

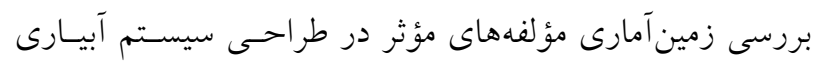

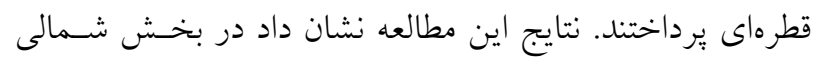

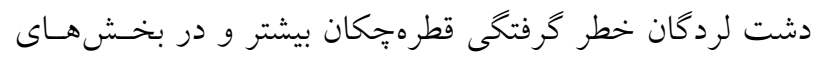

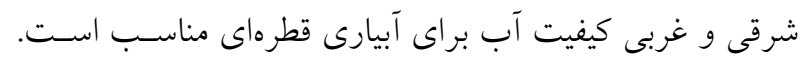

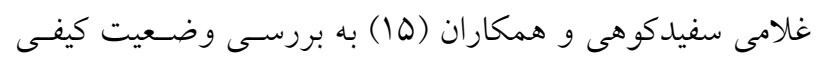

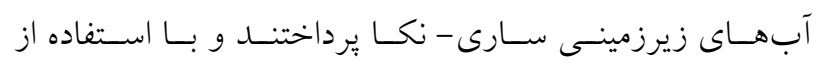

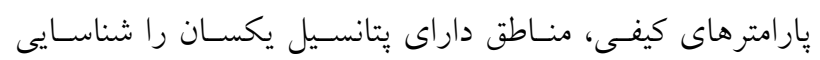

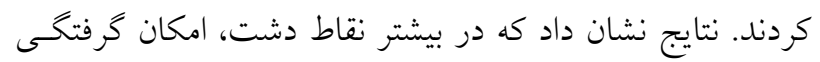

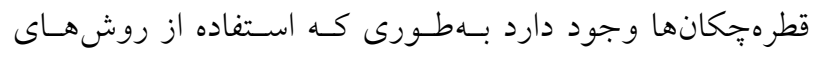

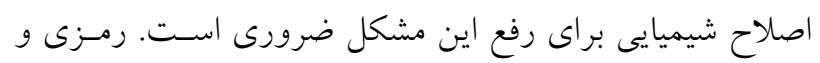

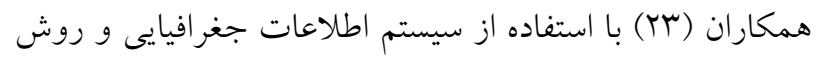

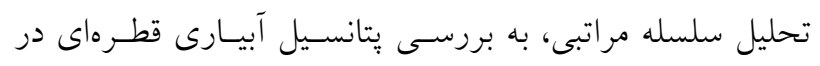

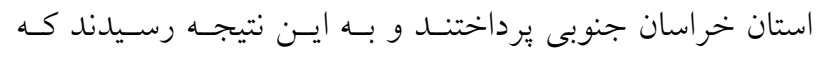

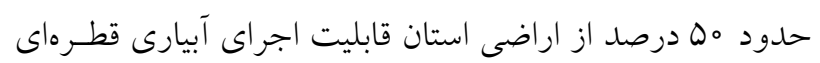

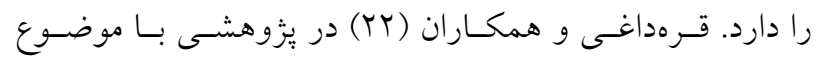

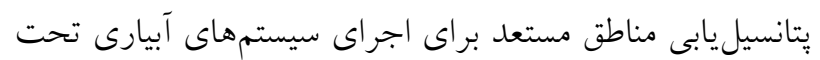

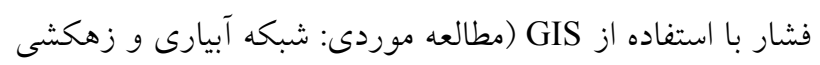

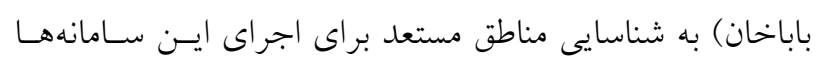

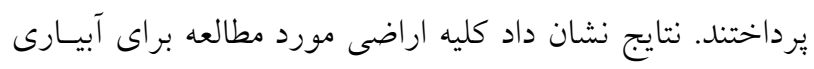

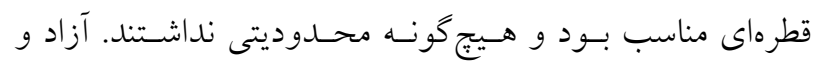

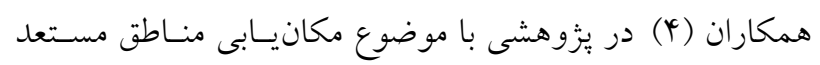

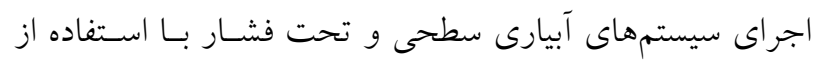

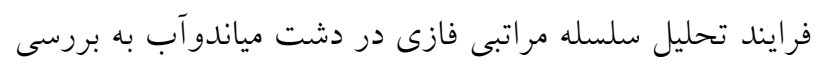
وضعيت دشت براى اجراى روشهاى آبيارى يرداختنـــ نتسيج

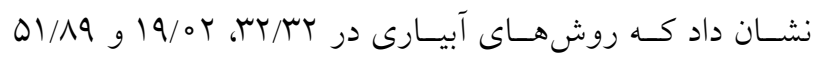
درصد از محدوده دشت داراى محدوديت جدى و خيلسى زيساد براى اجراى سيستم آبيارى سطحى، بـارانى و قطـرهاى هستـتند.

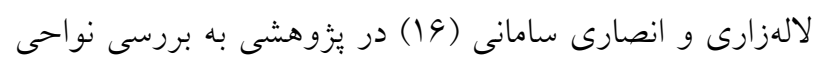

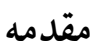

يكى از مهمترين بحرانهايى كه زندگى بشر را تحت تـأثير قـرار

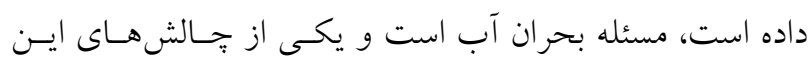

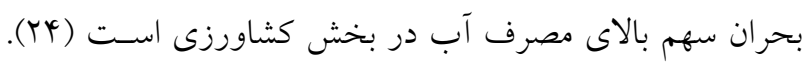

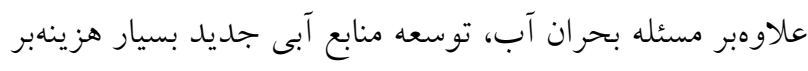

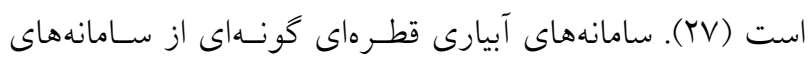

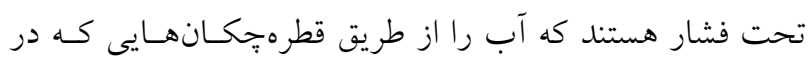

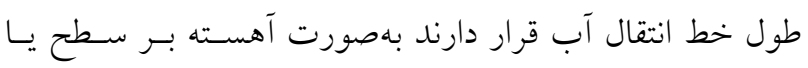

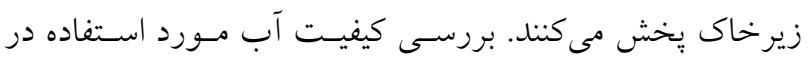

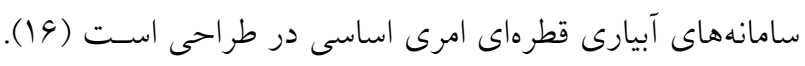

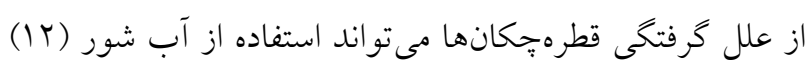

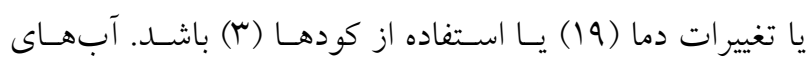

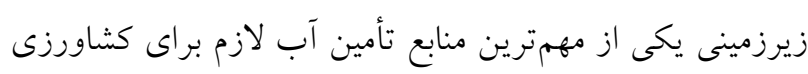

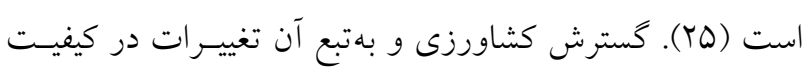

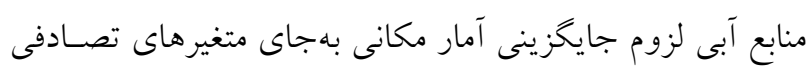

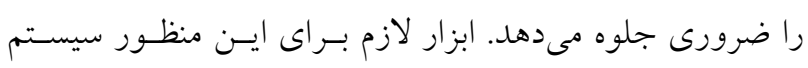

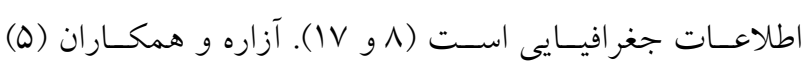

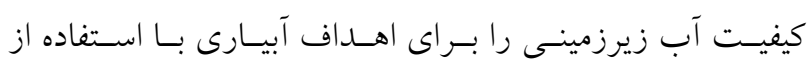
نرمافزار GIS در جنوب غرب ابت استان كرمان بررسى كردند. نتايج

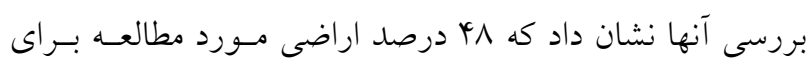

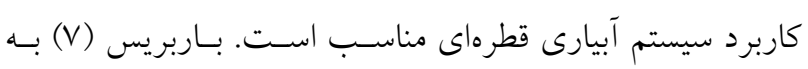

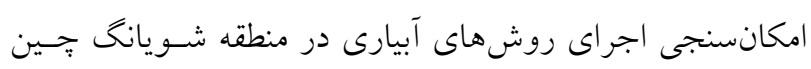

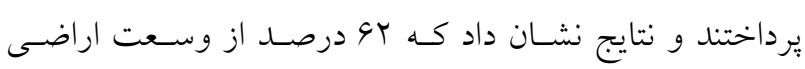
دشت براى اجراى سامانهاى قطرهاى مناسب هستند. قائمىزاده

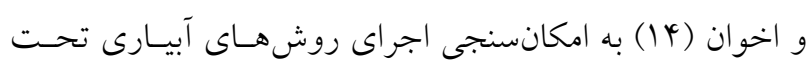

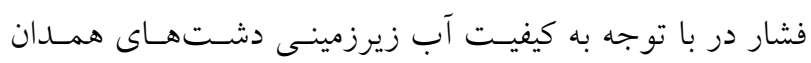

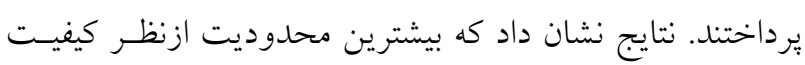

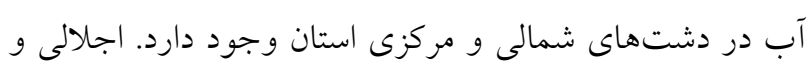

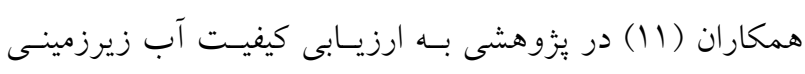

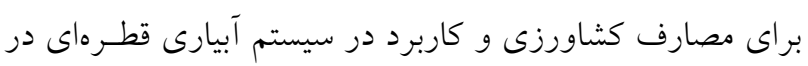

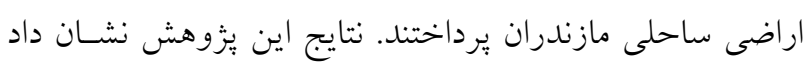
كه كيفيت بيشتر نمونهها براى كشاورزى در كـلاس 


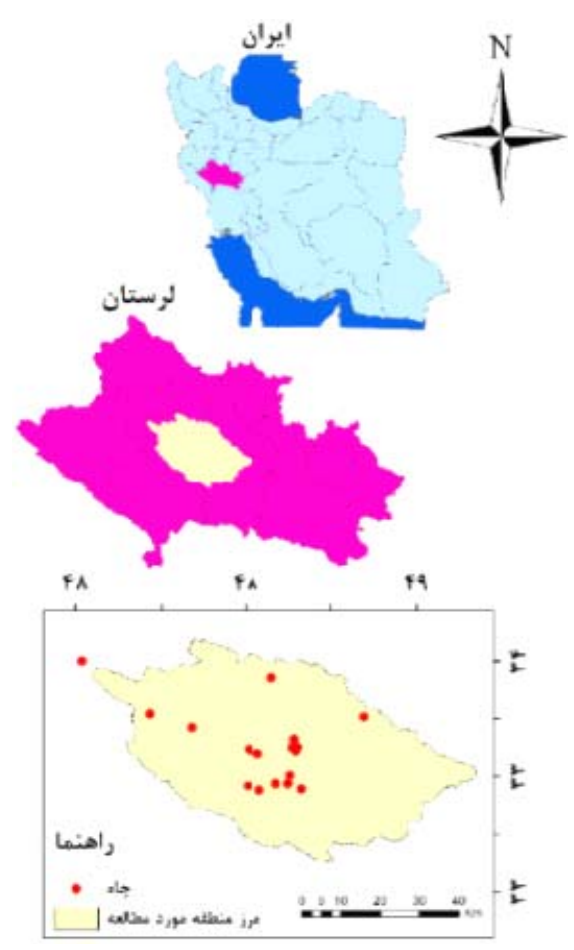

شكل 1. موقعيت جغرافيايى دشت خرمآباد در استان لرستان و ايران

آب مصرفى بر اساس شاخص اشباع لانزير (LSI) و با استفاده

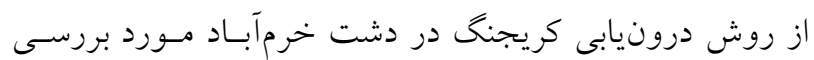

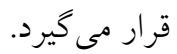

\section{مواد و روشها} معرفى منطقه مطالعاتى

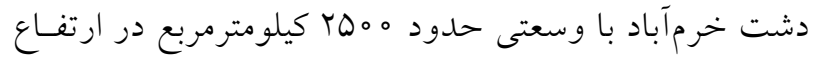

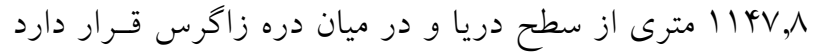

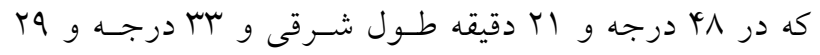

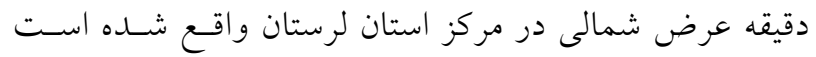

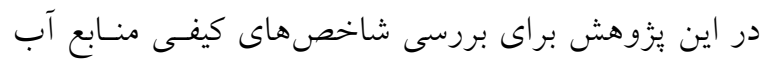

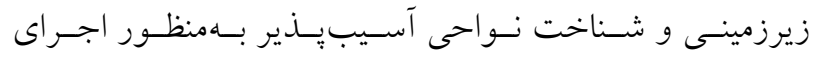

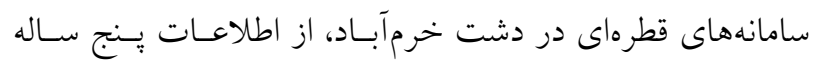

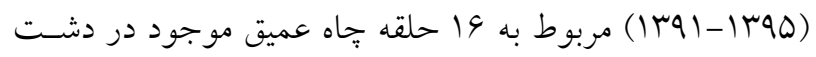

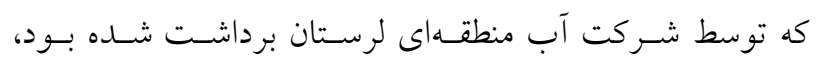

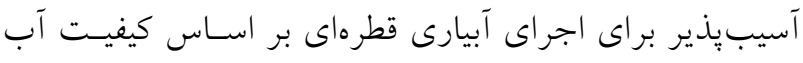

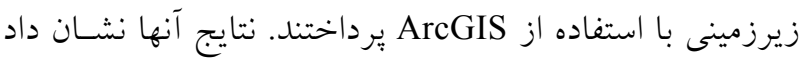
كه ه9 درصد جاهها داراى شاخص لانزير مثبت هستند. بت و

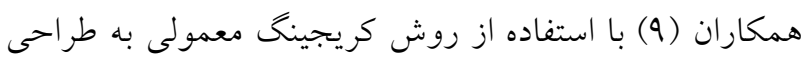

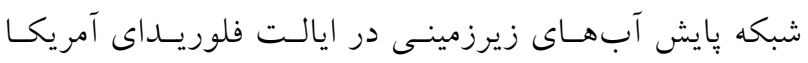

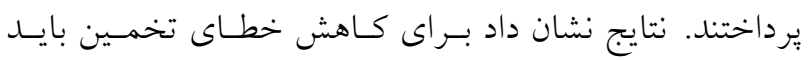

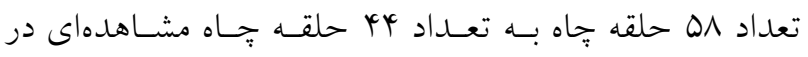
منطقه اضافه شود. دادرسى سبزوار (م إ) در مطالعـه تغييـرات

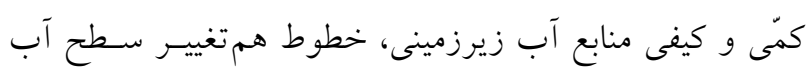
زيرزمينى را با روش كريجينگ و در محيط نرمافزارى Surfer

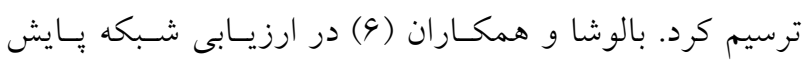

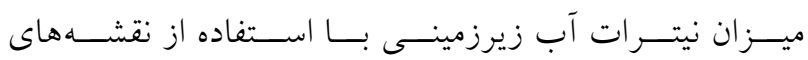

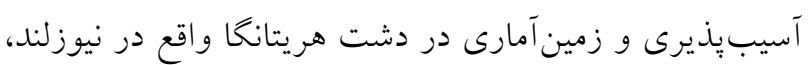

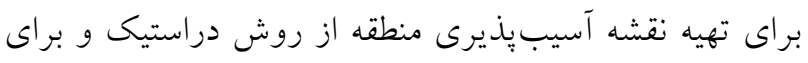
بررسى توزيع هاى مكانى منطقه از واريانس كريجينغ استفناده

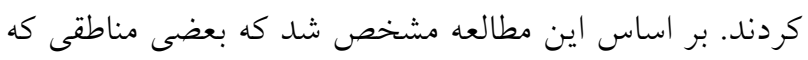

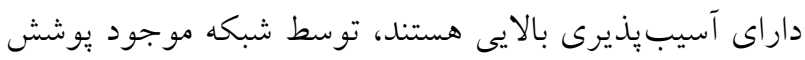
داده نمى شوند؛ بنابر اين بعضى مكانها بايد به شبكه اضـافه و

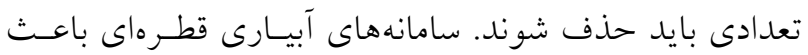
افزايش ميزان بهرهورى آب مى شوند و استفاده از اين سامانهها

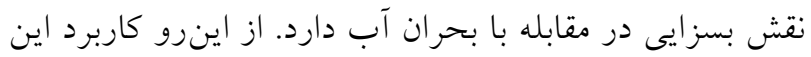

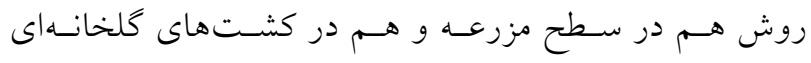

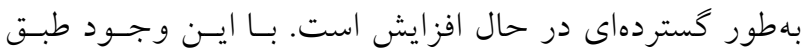

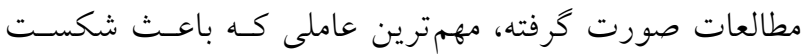

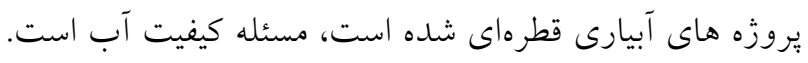

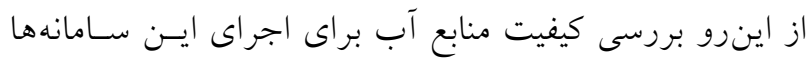

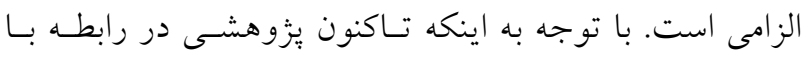

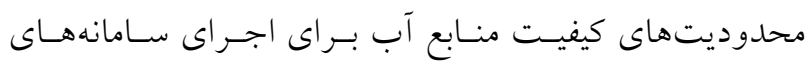

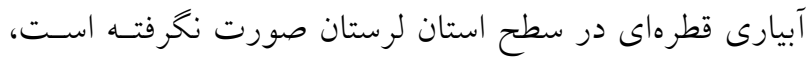

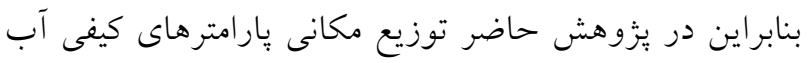

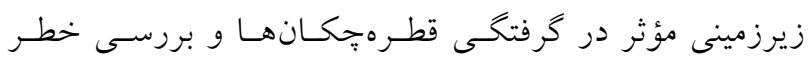

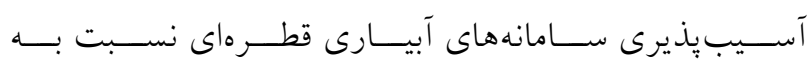


هم جوار توزيع مى كنند. روش خجندجملـهاى عـام يـك دامنـه

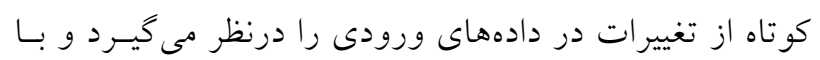
فواصل همسايكى در ينجره مشترى حساس است. بدين خونه كه ينجره حركت مى كند و مقادير سطحى در مركز هر ينجسره

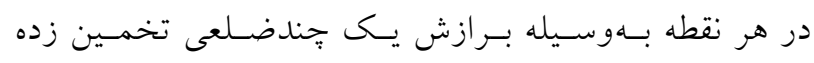

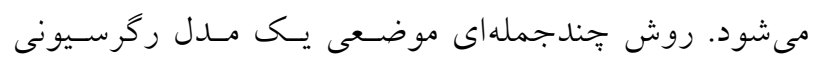

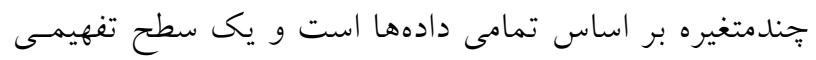

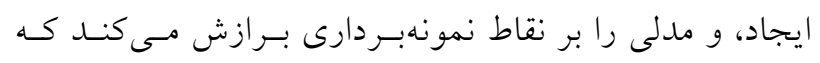

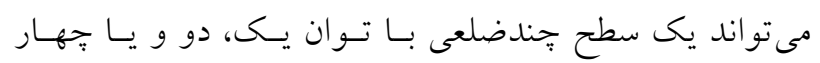

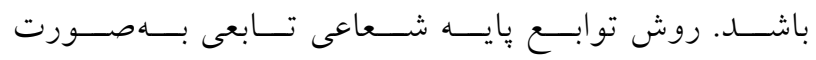

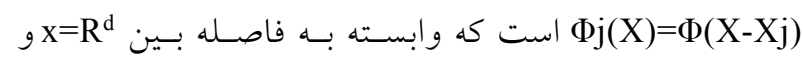

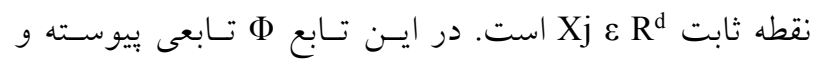

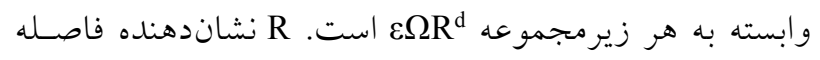
اقليدسى بين هر جفت نقطـه در مجموعـه $\Omega$ اسـت، اسـتفاده

\section{روش كر يجينگ} كريجينگ يكى روش تخمين است كه بر منطق ميانخين متحـرى

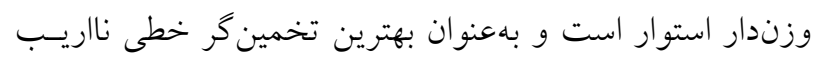

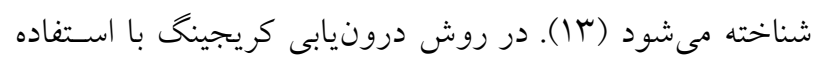

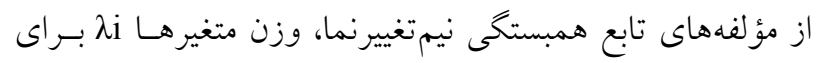

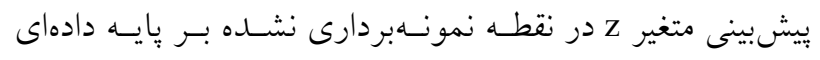

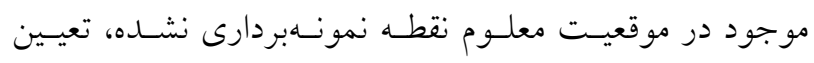

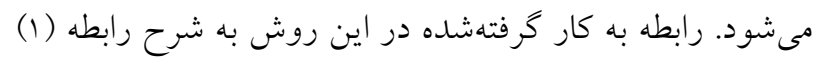

$$
\mathrm{Z}(\mathrm{X} \circ)=\sum_{\mathrm{i}=1}^{\mathrm{n}} \lambda \mathrm{i} . \mathrm{Z}(\mathrm{xi})
$$

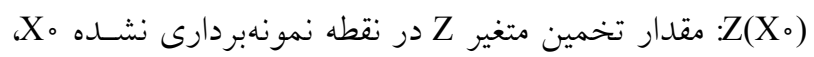

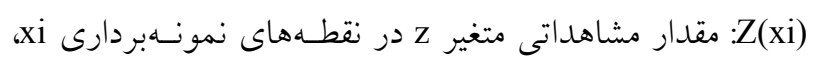
ii

انتخاب روش مناسب درونيابى

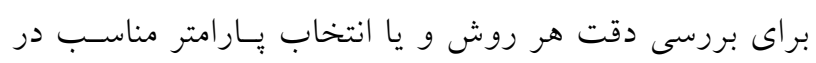

اسـتفاده شــــ مهـم تــــين معيارهــاى كيفـى آب در مصـارف

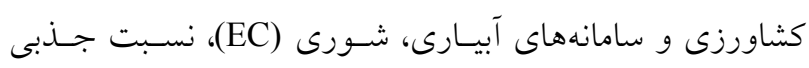

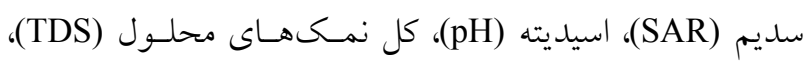

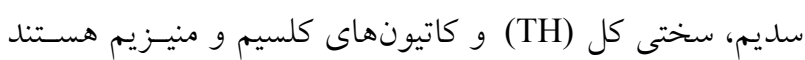
كه مورد بررسى قرار مى گيرند.

آزمون نرمال بودن دادهها

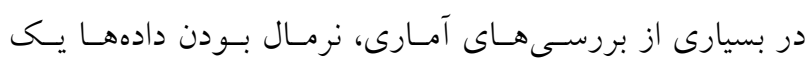

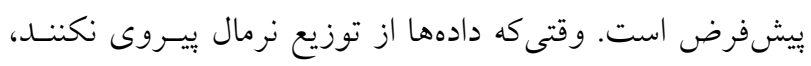

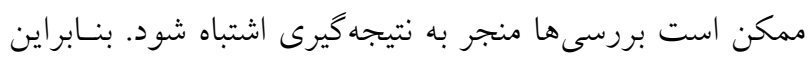

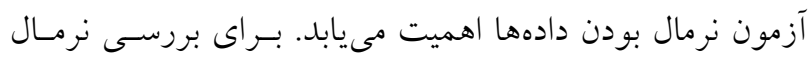

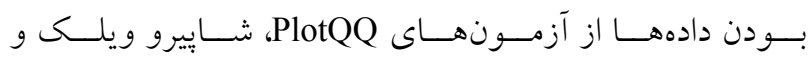
كلومو گروف - اسميرنوف با كمك نرم افزار SPSS استفاده شد.

\section{روشهاى درونيابى}

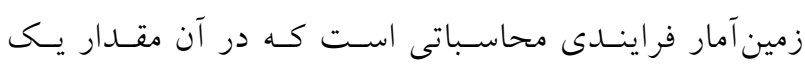

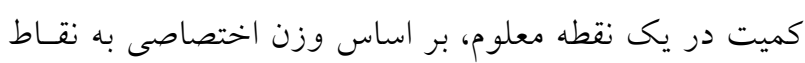

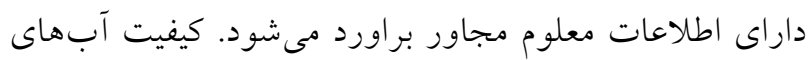

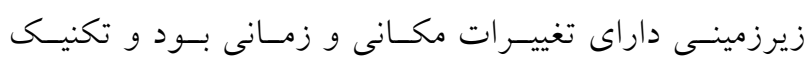

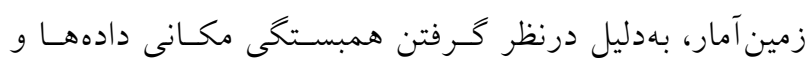

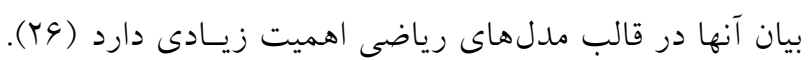

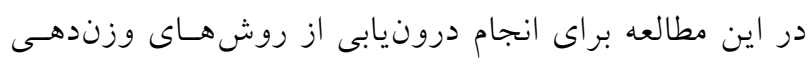

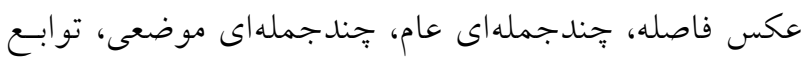

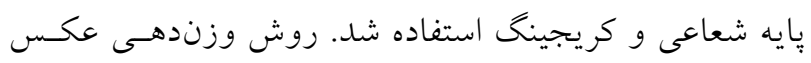

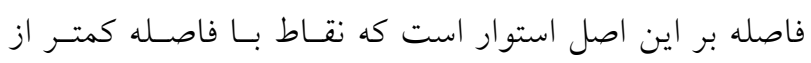
هم، نسبت به نقاط داراى فاصله بيشـتر، داراى مقــدار متغيـر

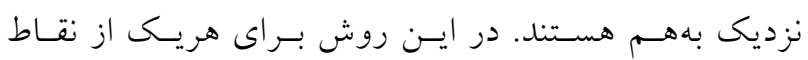

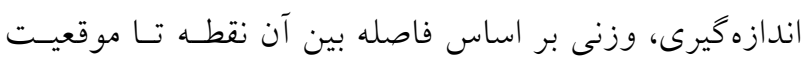

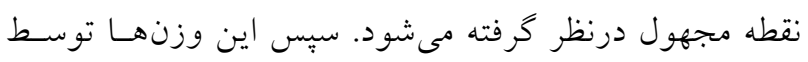

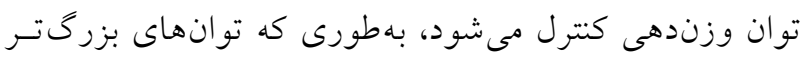

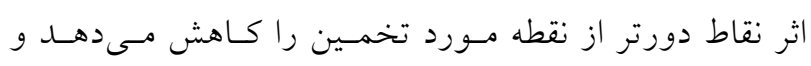

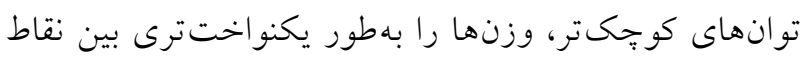


جدول 1. طبقهبندى آب كشاورزى بر اساس استاندارد ويلكاكس (YN)

\begin{tabular}{|c|c|c|c|c|}
\hline رده & SAR & رده & $\mathrm{EC}(\mathrm{dS} / \mathrm{m})$ & كيفيت \\
\hline S1 & $\mathrm{SAR}<1 \circ$ & $\mathrm{C} 1$ & $E C<r \Delta \circ$ & عالى \\
\hline S2 & $1 \circ<\mathrm{SAR}<1 \wedge$ & $\mathrm{C} 2$ & $r \Delta \circ<E C<V \Delta \circ$ & خوب \\
\hline S3 & $\mid \wedge<\mathrm{SAR}<Y \varphi$ & $\mathrm{C} 3$ & $V Q \circ<E C<r Y Q_{\circ} \circ$ & متوسط \\
\hline S4 & SAR $>$ Y 4 & $\mathrm{C} 4$ & $E C<Y r \Delta \circ$ & نامناسب \\
\hline
\end{tabular}

كيفى آب از نسبت جذبى سديم اصلاحشده استفاده شد كـه در رابطه (r) ملاحظه مىشود.

$\mathrm{SAR}_{\mathrm{adj}}=\frac{\mathrm{Na}}{\sqrt{\frac{\mathrm{Ca}+\mathrm{Mg}}{r}}}(1+(\wedge, \uparrow \mathrm{pHc}))$

اسيديته محاسبهشده بر اساس نتايج تجزيـه شـيميايى آب :pHc است و از رابطه (Y) محاسبه مىشود.

$\mathrm{PH}_{\mathrm{C}}=\mathrm{P}\left(\mathrm{Ca}^{++}+\mathrm{Mg}^{++}+\mathrm{Na}^{+}+\mathrm{K}^{+}\right)+\mathrm{P}\left(\mathrm{Ca}^{++}+\mathrm{Mg}^{++}\right)+$ $\mathrm{P}\left(\mathrm{CO}_{3}{ }^{-}+\mathrm{HCO}_{3}^{-}\right)$

قسـمت اول معادلـه مربـوط بـهـ ثابـت يونيزاسـيون و ضـريب

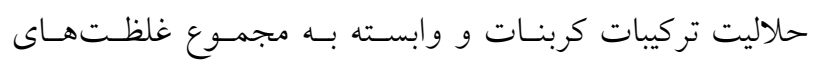
كاتيونهاى كلسيم، منيزيم، سديم و بِّاسيم است. پِارامترهاى اين

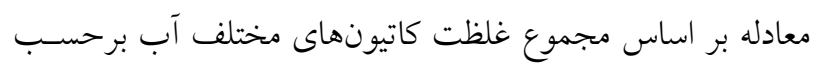

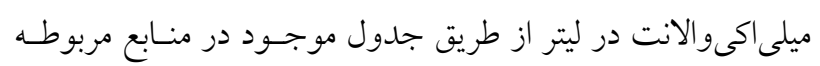
باعنوان استخراج اجزاى معادله pHc بهدست مى آيد (T).

\section{طبقهبندى بر اساس استاندارد ويلكاكس}

مقادير EC و SAR بر اساس اسـتاندارد ويلكـاكس در جهـار كلاس طبقهبندى مىشود (جدول (). در اين طبقـهبنـدى آب كشاورزى بر اساس EC و SAR بـه جههـار كـروه بـا كيفيـت خوب، قابلقبول، نامناسب و بد تقسيم مىشـوند كـه تركيـب اين ردهها آب را از نظر كشاورزى در جهار نوع كيفيت و 19 رده تقسيم مى كنند: شيرين: بــراى كشـاورزى كـاملاً بى ضـرر (C, $\left.S_{1}\right)$ (C, $\left.S_{\uparrow}, C_{Y} S_{1}, C_{Y} S_{Y}\right)$
آنها نياز بــه ارزيـابى وجــود دارد. در ايسن زمينـه روشهـاى

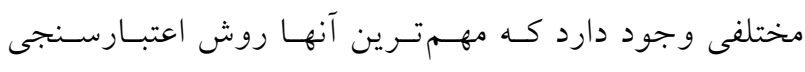
حذفى (Cross-Validation) يا تقاطعى است. در ايسن روش، مقايسهاى بين نقاط اندازهذيـرى شـده و مقـادير تخمينى بـا استفاده از روشهاى مشخص صورت مى گيرد. به اين ترتيب كه يك نقطه حذف شده و با استفاده از سـاير نقـاط و اعمـال روش درونيابى مورد نظـر، بـراى ايـن نقطـه تخمسين انجـام مى گيرد. سيس اين نقطه به محل خود بركردانسـه مسى شـود و

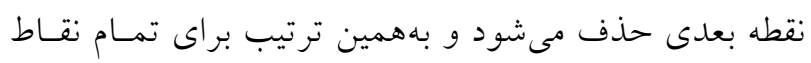
براورد صورت مى گيرد، بهطورى كه در بايان دو ستون شامل

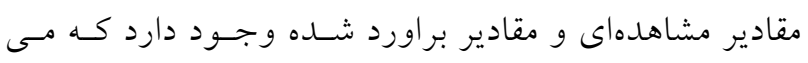

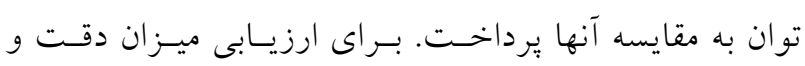
خطا ميان مقادير مشـاهدهاى و تخمينسى معيارهـاى مختلفى نظير مجموع مربعات باقيمانده، ميـانخين مربعـات باقيمانـده، استفاده از روش هاى مقايسـه آمـارى نظيـر آنـاليز واريـانس، كاىاسكوار وجـود دارد. در ايسن يـزّوهش از شـاخص جـــر

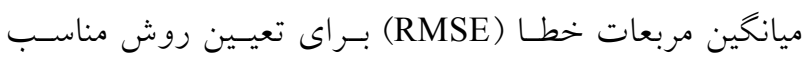

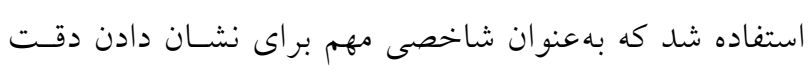
تحليل مكانى در GIS شناخته مى شود (Yo) و از طريق رابطه (r) و بــا اسـتفاده از دادههــاى مشـاهداتى و ييشبينسى شـــه

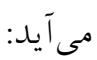
$\operatorname{RMSE}=\sqrt{\frac{\sum_{\mathrm{t}=1}^{\mathrm{n}}\left(\mathrm{x}_{\mathrm{i}}-\overline{\mathrm{x}}\right)^{r}}{\mathrm{n}}}$

از بين روش هاى مختلف هر كدام كه ميزان RMSE كمترى داشته باشد بهعنوان روش مناسب انتخاب مىشـود. در ايسن يثزوهش روش درونيـابى كريجينـ داراى كمتــين ميـزان خطا بود. بعد از انتخاب روش درونيابى مناسـب اقـدام بـهـ يجهنهبنـدى فاكتورهـاى مختلـف در سـطح دشـت مطالعـاتى مى شود. يارامترهاى EC و SAR اولين گزينههاى قابل بررسى بـراى تعيين شرايط كيفى فيزيكوشيميايى محيط ريشه اسـت. بـهدليـل تأثير رسوبات كربنات در شرايط قليايى، براى بررسى وضـعيت 
جدول r. نتايج آزمونهاى كلوموگروف- اسميرنوف و شاييرو- ويلك قبل و بعد از نرمال كردن دادهها

\begin{tabular}{|c|c|c|c|c|}
\hline \multicolumn{2}{|c|}{ شاييرو - ويلك } & \multicolumn{2}{|c|}{ كلوموگروف - اسميرنوف } & \multirow{2}{*}{ آل } \\
\hline سطح معنى دارى بعد & سطح معنى دارى قبل & سطح معنى دارى بعد & سطح معنى دارى قبل & \\
\hline$\circ / \circ \vee \wedge$ & 。 & $0 / r$ & $\circ / 0 \circ Y^{k}$ & $\mathrm{EC}$ \\
\hline$\circ / T \circ V$ & 。 & $0 / r$ & $\circ / \circ \circ V$ & SAR \\
\hline$\circ / V \mu^{r}$ & $0 / 001$ & $0 / r$ & $\circ / 0 \circ \wedge$ & $\mathrm{TH}$ \\
\hline.$/ 009$ & 。 & $0 / 191$ & O/O० & TDS \\
\hline $0 / 909$ & -/VGI & $0 / r$ & $0 / Y$ & $\mathrm{pH}$ \\
\hline $0 / 949$ & 。 & $0 / r$ & 。 & $\mathrm{Na}$ \\
\hline
\end{tabular}

را قبل و بعد از نرمال شدن نشان مىدهند. همـانطور كـه بيـان شد در اين نمودارها درصورتى كه توزيع دادههـا نرمـال باشـد، انتظار مىرود كه نمـودار حاصـل در امتـداد يـك خـط راسـت

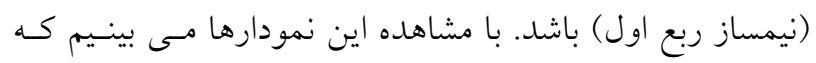

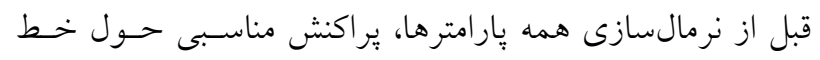

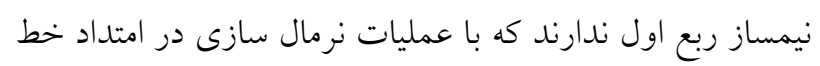
يكراست توزيع مىشوند.

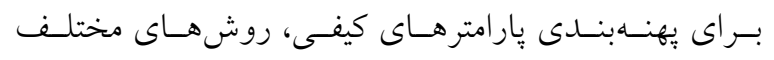
درونيابى مقايسه شد. جدول (r) نشاندهنده نمـودار و مقـادير شاخص RMSE براى يارامترهاى مورد بررسى است. بـا توجـه به نتايج اين مقايسه، روش درونيابى كريجينخ معمولى بهعنوان مناسبترين روش درونيابى انتخــاب شـــ. مطالعـاتى همجهـون دادرسى و سبزوار (0 (1)، بالوشا و همكاران (9) و احمد (1) نيـز بيان شده است كه روش كريجينگ و نتايج حاصل از آن بهدليل لحـاظ واريـانس مكــانى، موقعيـت مكـانى، موقعيـت و توزيـع نمونهها قابل اعتماد است و نسبت به روشهـاى ديخـر، بيشـتر مورد استفاده يزوهشخران در اين گونه مطالعات بوده است. در كام نخست يُرامترهـاى EC و SAR بررسسى شـدند. در طبقهبندى اين ويارامترها بـر اسـاس اسـتاندارد ويلكــاكس بــراى مصارف كشاورزى AY/D درصد از منسابع مـورد بررسسى در رده

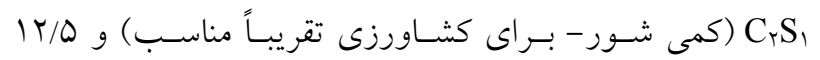
درصد از منابع در رده اCHS (شور- براى كشاورزى بـا اعمـال

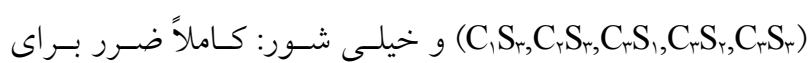
كشـــاورزى (C, افزايش شماره كلاس شرايط خاك در محسيط ريشـه بـه لحساظ نقوذيذيرى و قابليـت جـذب آب بـهوسـيله گيـاه نامناسـبـــر مى شود (1) - (1). (1) بعد از بررسى EC و SAR به بررسـى يّارامترهـاى مـؤثر در

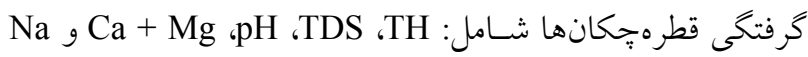

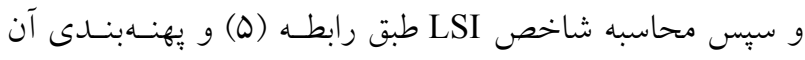
يرداخته شد. $\mathrm{LSI}=\mathrm{pH}-\mathrm{pHc}$ كه pHc از رابطه (†) قابل محاسبه است.

نتايج و بحث نتايج آزمونهاى شاييرو - ويلك و كلومو گروف - اسـميرنوف و بررسى آماره سطح معنى دارى نشـان داد كـهـ بـهـز PH PH تمـامى يارامترها بـهدليـل دارا بـودن سـطح معنسىدارى كمتـر از هـ/ غيرنرمال هستند. در اين شرايط نياز به نرمالسازى دادهها است. با روش لكاريتم گيرى نرمالسازى دادهها صورت گرفت. جدول (Y) دربردارنده مقادير سطح معنىدارى قبل و بعد از نرمالسازى

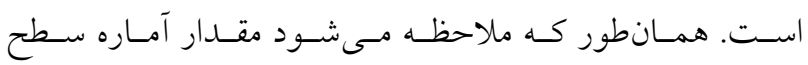
معنى دارى بعد از نرمالسازى بيشـتر از هـ/ اسـت. شـكل (r) نمودار حاصل از آزمون نرمالى دادههاى EC و 

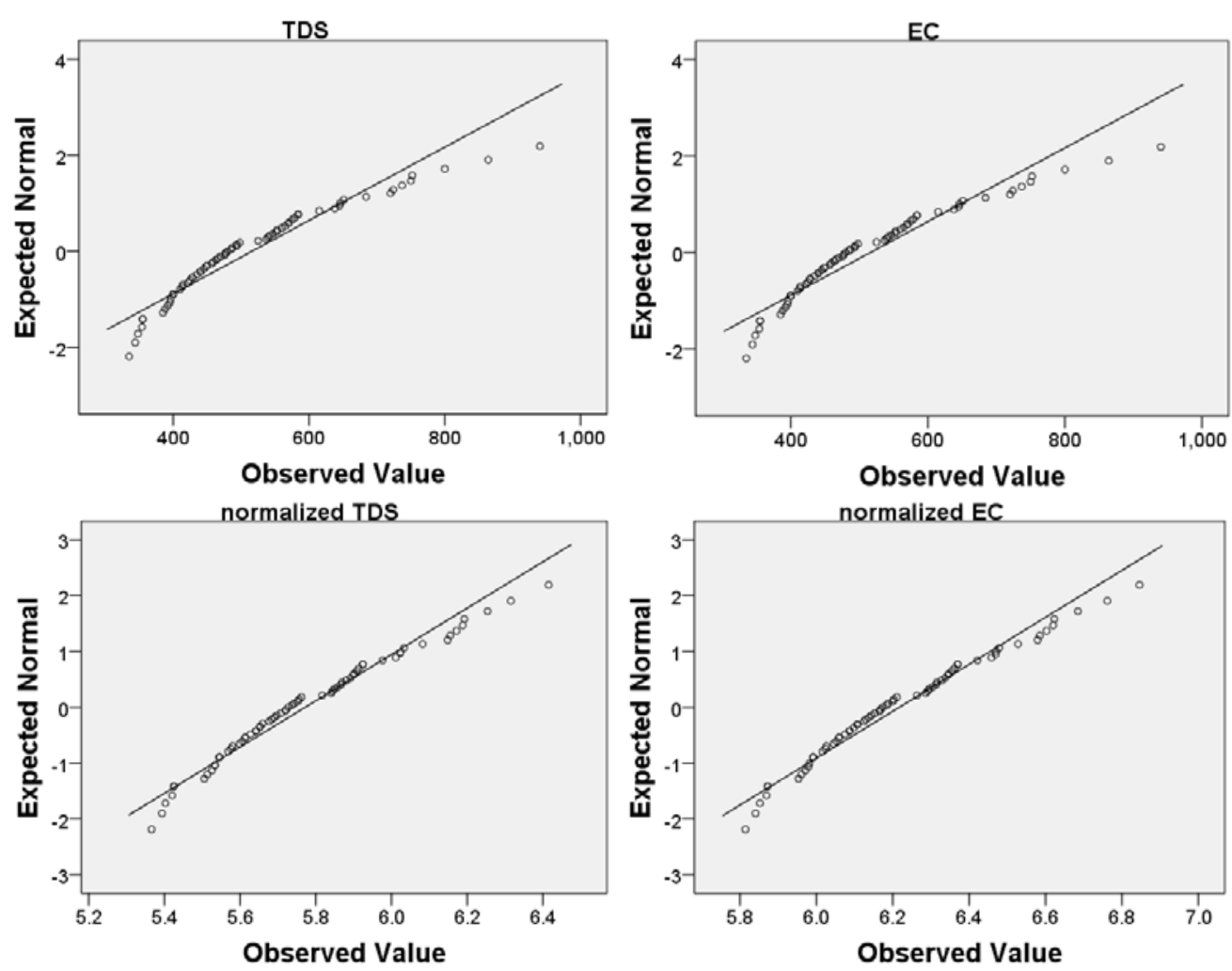

شكل r. نتايج آزمون QQ- Plot قبل و بعد از نرمال شدن دادهها

جدول r. مقادير شاخص RMSE روشهاى مختلف درونيابى

\begin{tabular}{|c|c|c|c|c|c|c|c|}
\hline \multicolumn{7}{|c|}{ RMSE } & شاخص خطا \\
\hline (meq/L) & $\begin{array}{c}\text { سديم } \\
\text { (meq/L) }\end{array}$ & كل مولواد جامد (meq/L) محل & سختى كل & $\begin{array}{l}\text { شورى } \\
(\mathrm{dS} / \mathrm{m})\end{array}$ & نسبت جذبى سديم & $\mathrm{pH}$ & روش درونيابى \\
\hline$\circ / 01$ & $\circ / T Q$ & $9 V / 9$ & $K T / Y$ & $1 \circ r / r$ & $0 / 14$ & $\circ / r$ & كريجينگ معمولى \\
\hline$\circ / \Delta \Delta$ & $0 / T V$ & $99 / 11$ & $49 / 09$ & $104 / \pi$ & $\circ / 10$ & $\circ / K Q$ & وزندهى عكس فاصله \\
\hline$\circ / \Delta \mu$ & $\circ / 4 q$ & VG/A & $\mathrm{kY} / 9$ & $119 / 1$ & $0 / \pi \mu$ & $0 / T_{1}$ & جند جملهاى عام \\
\hline$\circ / \Delta r$ & $\circ / Y \wedge$ & $V T / \Psi$ & $\mu \varphi / r$ & $110 / 9$ & $0 / 19$ & $0 / Y T$ & جندجملهاى موضعى \\
\hline$\circ / Q Y$ & $\circ / \mu$ & $9 V / 9$ & Fr/ & $1 \circ r / 0$ & $0 / 19$ & 每 & توابع پِايه شعاعى \\
\hline
\end{tabular}

كياه مطلوب است. درحالى كه در شمال و مركز افزايش كـلاس

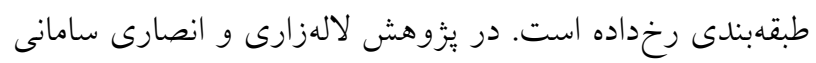

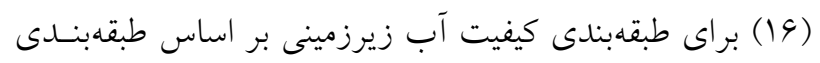

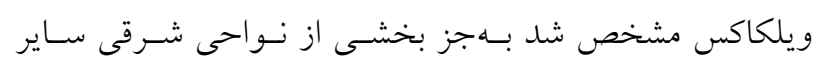

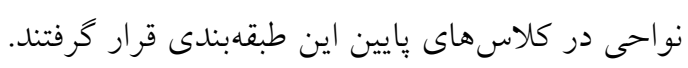

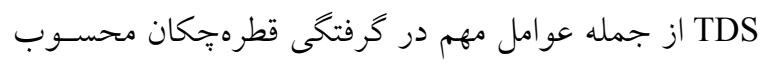

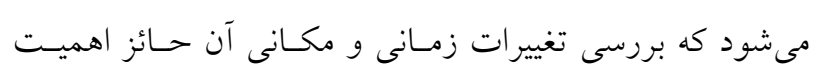

تمهيدات لازم) قرار كرفتند (شـكل ؟). بـراى تعمسيم از حالـت

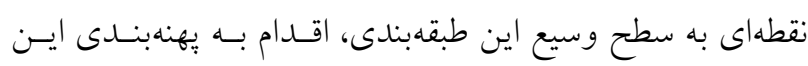

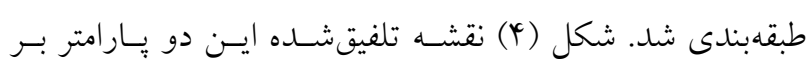

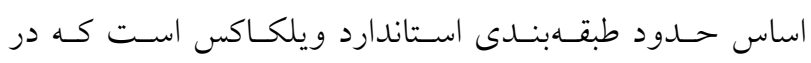
شناخت نواحى آسيب بذير مؤثر است. مطابق اين نقشه، نـواحى آنى

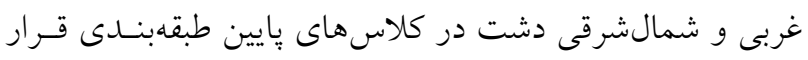

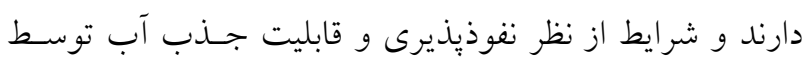



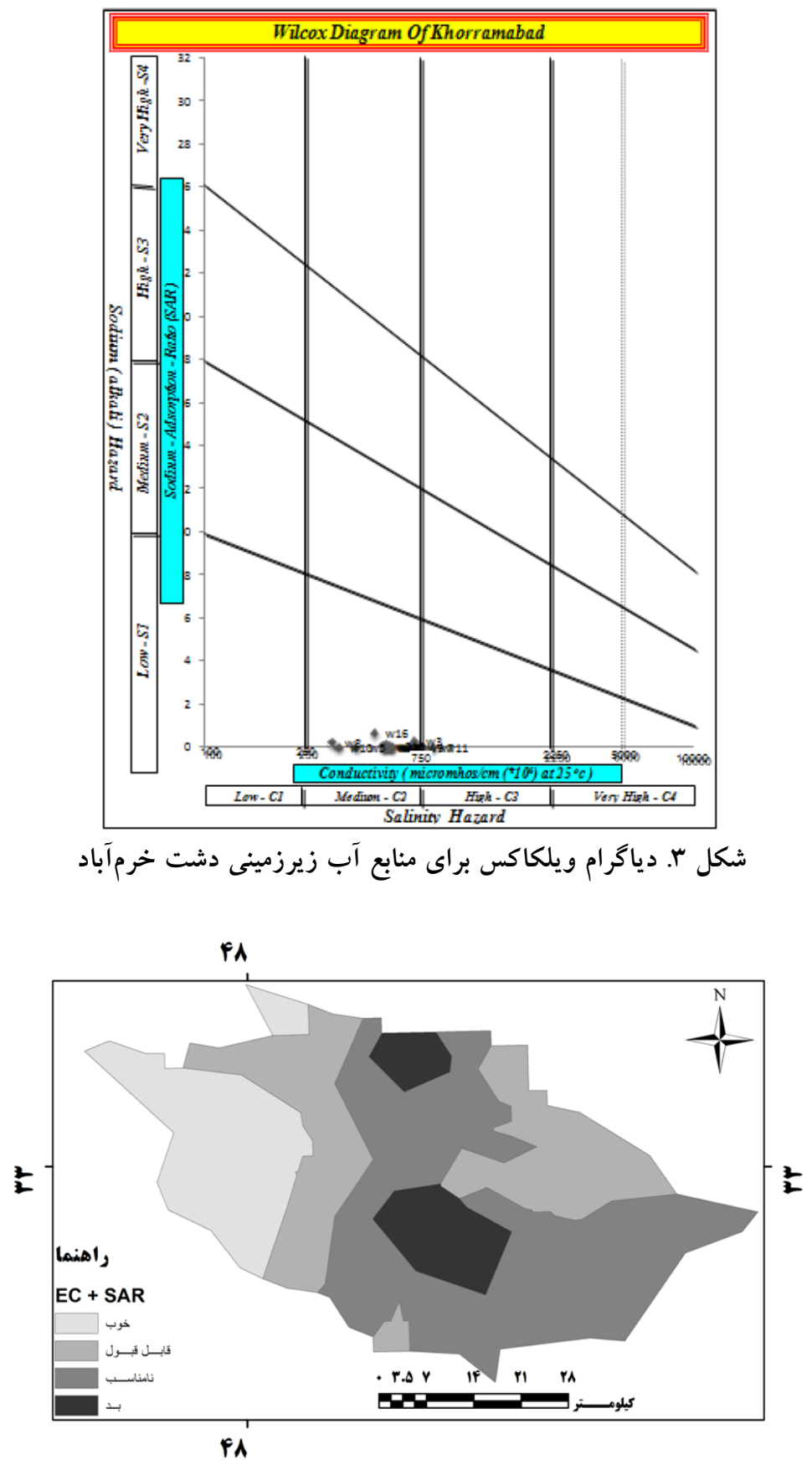

شكل †. نقشه طبقهبندى آب زيرزمينى بر اساس شورى (دسىزيمنس بر سانتى متر) و سديمى

است. طبقدبندى اين يارامتر از نظر خطر كرفتخى به اين صورت سال در سطح دشت نشان مىدهد. با توجه بـه نقشـه، كمتـرين

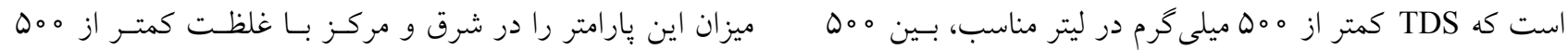

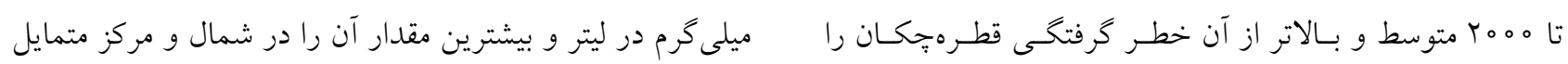

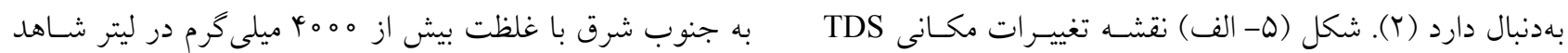

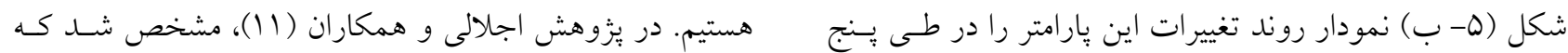



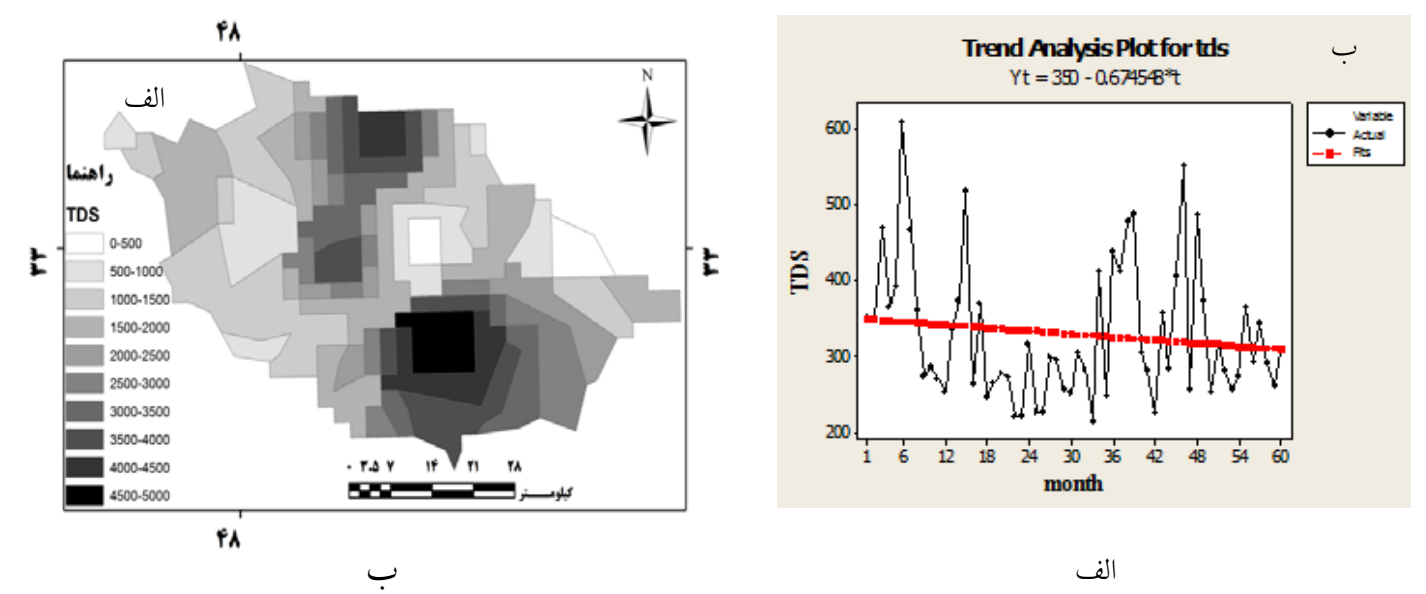

شكل ه. الف) نقشه تغييرات مكانى و ب) روند تغييرات ينجساله كل نمكهاى محلول در آب (ميلى گرم در ليتر)

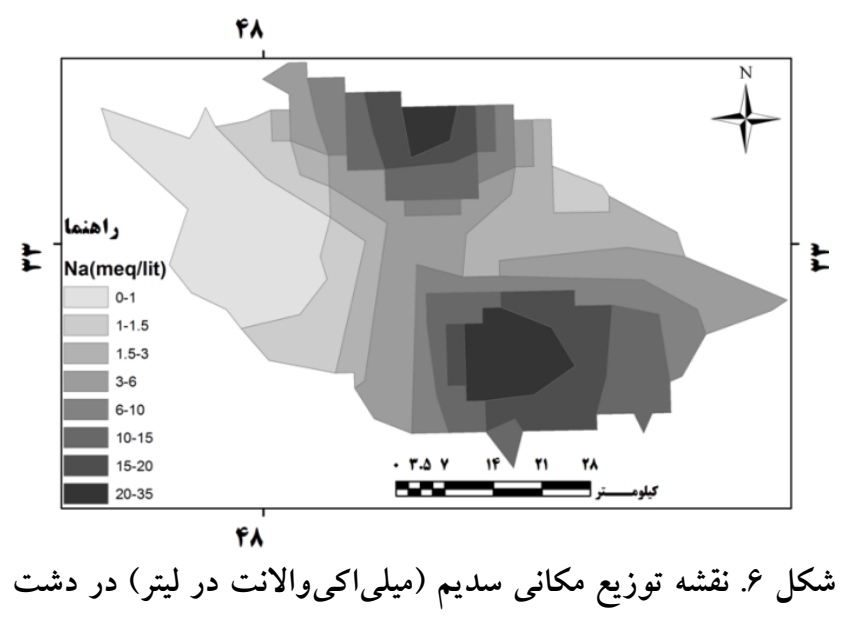

سديم بيش از ب ميلى اكىوالانت در ليتر براى سامانههاى بـارانى

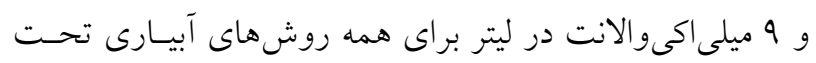

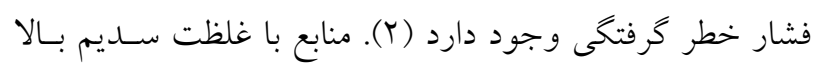

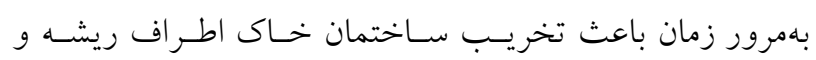

$$
\text { تبديل به خاك سديمى مى شوند. }
$$

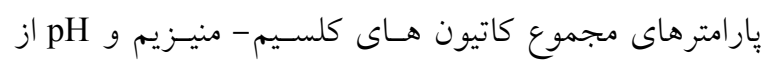

عواملى هستند كه بر هم اثر كذاشته و موجب تغييرات شيميايى

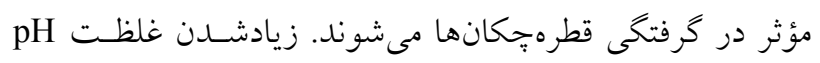

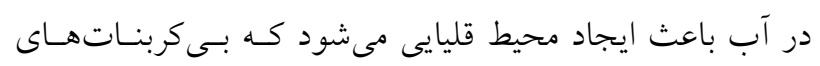
كلسيم و منيزيم طبق واكنش شيميايى (رابطه 9) به كربناتهـاى كلسيم و منيزيم تبديل مىشود. اين تبديل شيميايى خطر ايجـاد

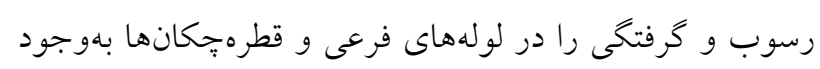

$$
\text { مى آورد. }
$$

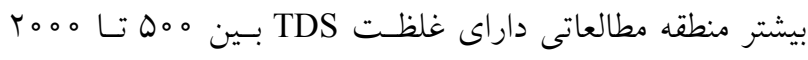
ميلى گرم در ليتر است. نمودار روند تغييرات زمانى TDS بيانخر كاهش غلظت آن در طى ينج سال است كه بيشترين غلظـت در ماه ششم و كمترين غلظت در ماه سى و سوم دوره ينجساله رخ داده است. جنانجه املاح محلول در آب زيرزمينى بيشتر از نمـكهـاى سديمى تشكيل شده باشد، اثرات مخرببترى بر خاى خواهنــ

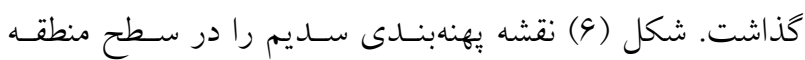
نشان مى دهد. با توجه به اين نقشه نـواحى غربسى و شـرقى بـا غلظت سديم كمتر از يك ميلسى اكىوالانـت در ليتـر كمتـرين غلظت را دارند كه با حركت بهسمت شمال و جنوب شـرق بـر

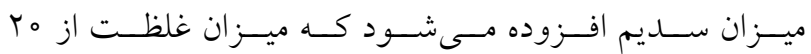
ميلى اكى الانت در ليتر متجاوز است. در منابع آبسى كـهـ غلظـت 


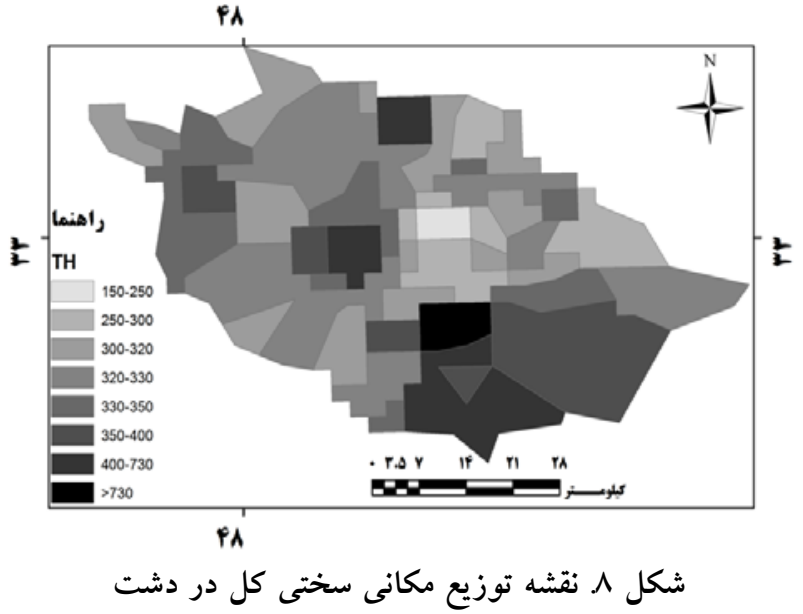

شكل (N) نقشه يهنهبندى TH در سطح دشت خرم آباد است. بـا

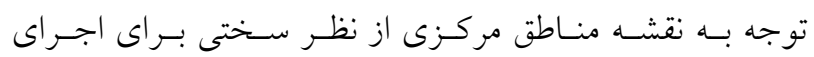

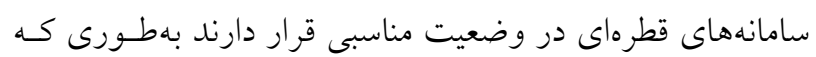

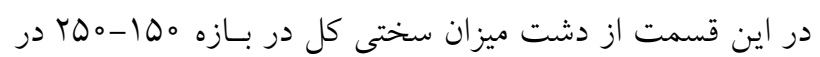

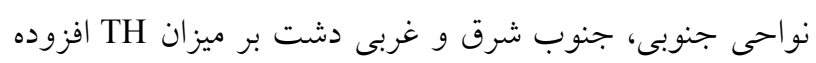

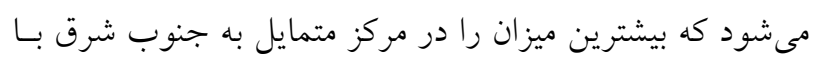

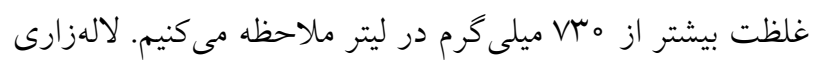

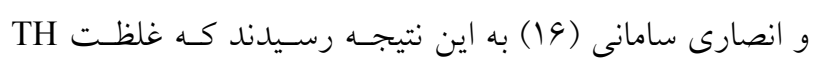

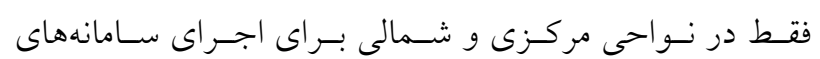

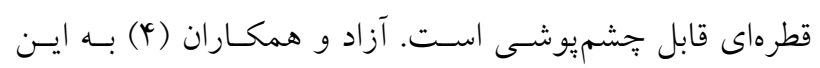

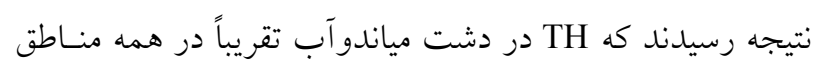

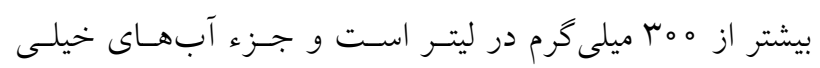
سخت بوده و خطر رسوب املاح وجود دارد.

شاخص اشباع لانزير (LSI)

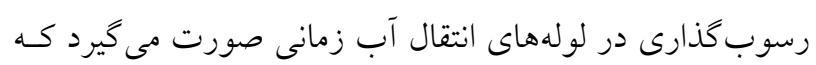

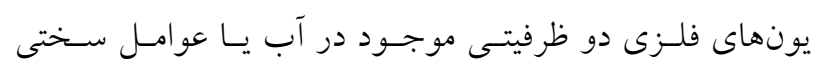

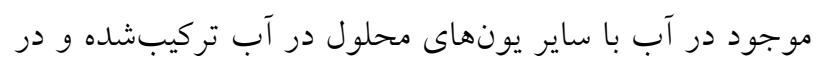

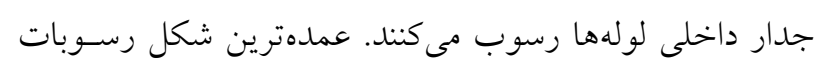

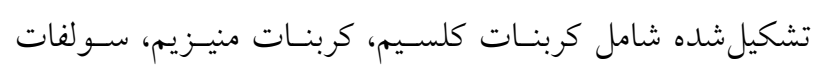
كلسيم و كلريد منيزيم است. شاخص اشباع لانزيـر، مهـم تـرين

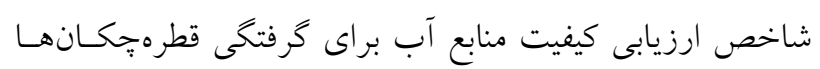

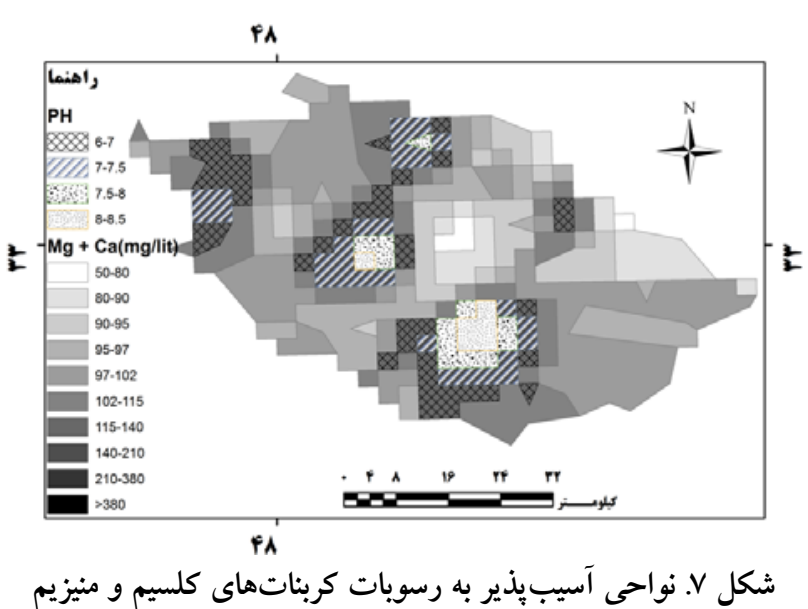

$[\mathrm{Ca}, \mathrm{Mg}]\left(\mathrm{HCO}_{r}\right)_{r} \stackrel{\mathrm{OH}}{\longrightarrow}[\mathrm{Ca}, \mathrm{Mg}] \mathrm{CO}_{r} \downarrow$

$$
+\mathrm{CO}_{r} \uparrow+\mathrm{H}_{r} \mathrm{O}
$$

״نانجه مجموع غلظت كلسيم و منيزيم از مه ميلى خـرم در ليتـر و

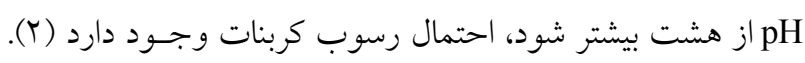

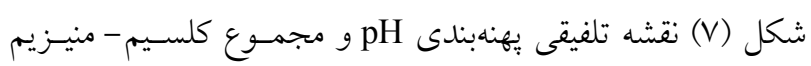
است كه تغييرات اين بارامترها را در سطح دشت نشان مى دهد.

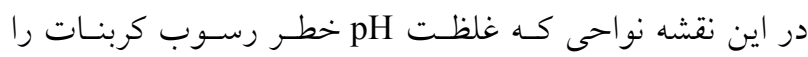

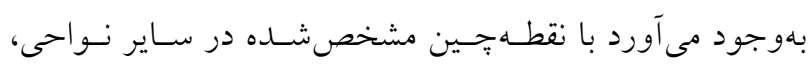

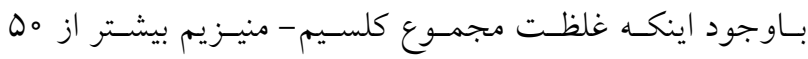

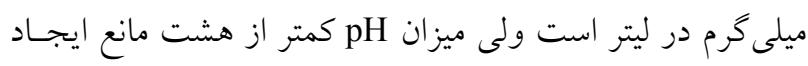

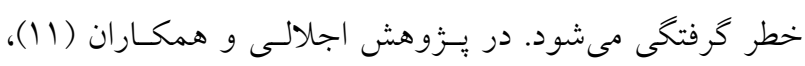

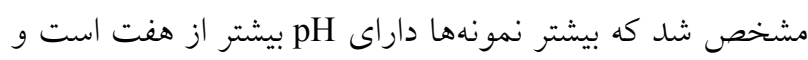

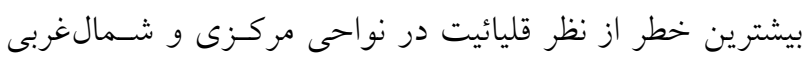
وجود دارد.

سختى آب پارامترى است كه معمولاً بهصورت مجموع غلظت دارد يونهاى كلسيم و منيزيم برحسب ميلى گرم در ليتر به دست مى آيد؛ بنابراين، اكر غلظت اين كاتيونها بر حسب ميلى كرم در ليتر باشد مئد

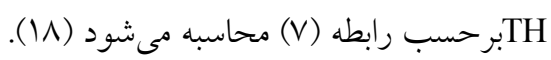
$\mathrm{TH}=r / \Delta \times \mathrm{Ca}^{r+}+r, / \times \mathrm{Mg}^{r+}$

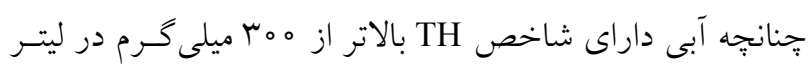

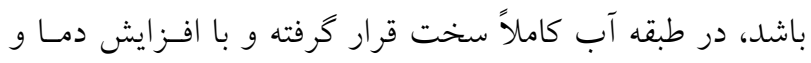

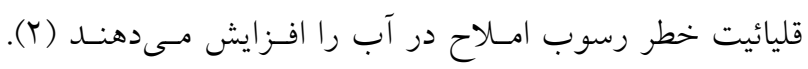



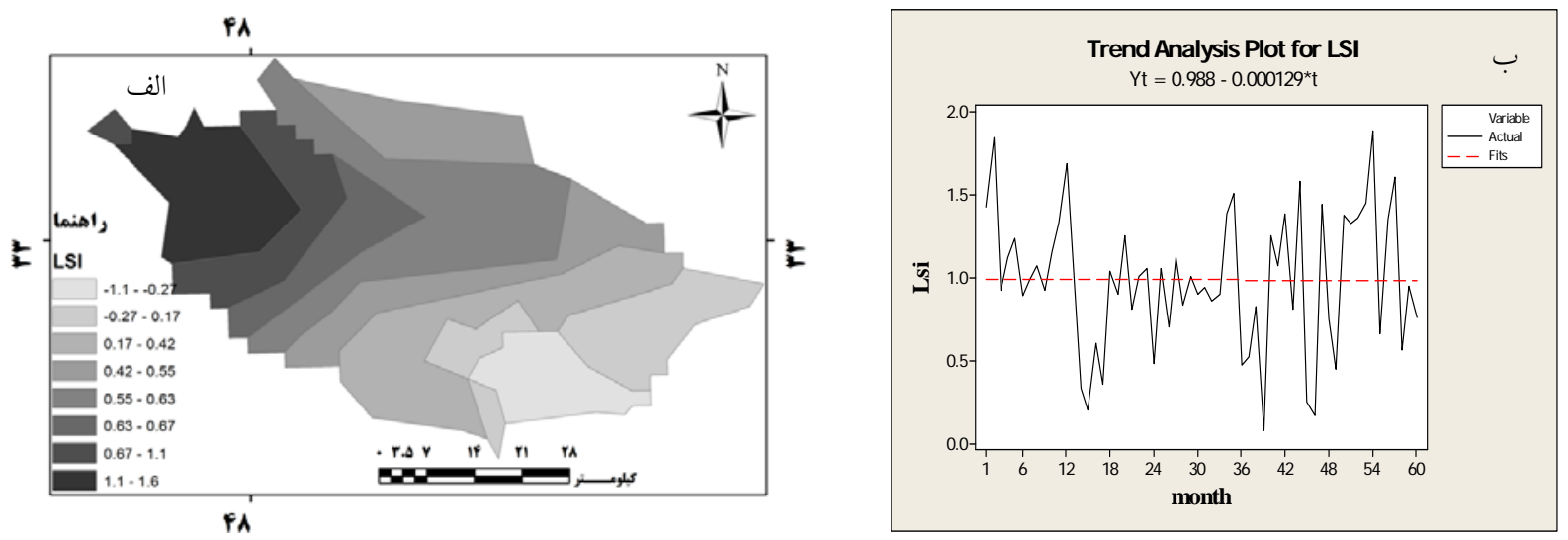

شكل 9.

\begin{tabular}{|c|c|c|}
\hline درصد & مساحت (كيلو مترمربع) & مقدار LSI \\
\hline$V / \circ 9$ & $I V V / r$ & -1/1 تا \\
\hline$M / 4 V$ & MI/A & -。/TV تا IV \\
\hline$|0 / 9|$ & $r q \circ / 1 r$ & O/VV تL \\
\hline IV/rT & $k r \circ / \Lambda$ & 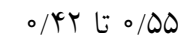 \\
\hline $19 / 49$ & $Y \wedge V / r$ & س س/ه تا \\
\hline$V / \Psi V$ & $1 \wedge 9 / V$ & 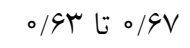 \\
\hline$\Lambda / \Lambda \Lambda$ & TYY/OY & 1/1/ 19V ا \\
\hline $11 / 29$ & $r q r / 9$ & 1/9 إ 1/19 \\
\hline
\end{tabular}

از قطرهجهانهاى حساس به گرفتخـى اسـتفاده نشـود. نمـودار روند تغييرات شاخص LSI بيـانخر كـاهش جزئسى ميـزان ايسن

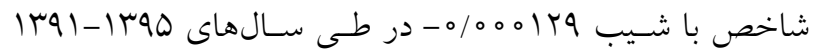
است. بهطورى كه بيشترين ميزان اين شـاخص در مـاه ينجـاه و جهارم و كمترين ميزان آن در ماه سـى و سـوم رخ داده اسـت. آزاد و همكاران (Y) نيز در مطالعه خود به اين نتيجه رسيدند كه LSI در هيج نقطهاى كمتر از صفر نيست كه با نتايج يزوهش حاضـر

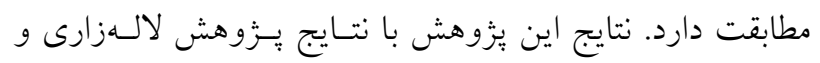

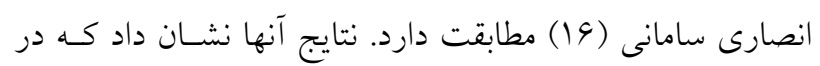
بخش غربى دشت انديمشك- دزفول مقدار شاخص LSI مثبت
بهمنظور اجراسازى سامانههاى قطرهاى است. شـكل (9- الـف) نشاندهنده نقشه تغييرات مكانى شاخص LSI و شكل (9- ب) نمودار روند تغييرات ميزان LSI در طى ينج سال و جــدول (Y)

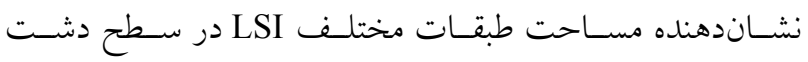
خرمآباد است. مطابق اين نقشه كمتـرين ميـزان LSI در نـواحى جنوبشرقى با مساحتى بيش از 19 درصــ از دشـت، در بـازه

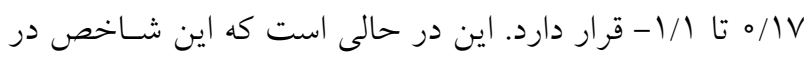
نواحى غربى داراى مقادير بـالاتر از يـك اسـت؛ بنـابراين ايسن

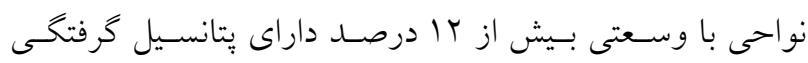
قطرهجّان بيشترى نسبت بـه سـاير منـاطق هسـتند، از ايـنـرو توصيه مىشود در اين قسمت ها براى اجراى سامانهاى قطرهاى 


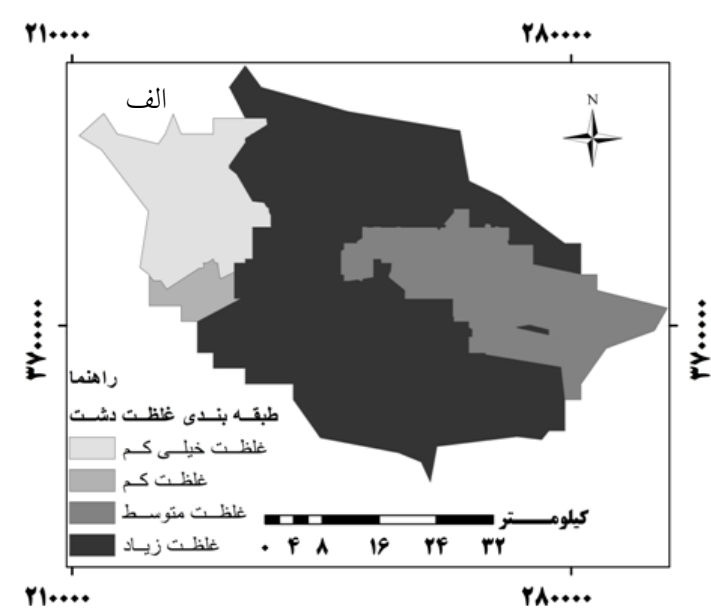

ب

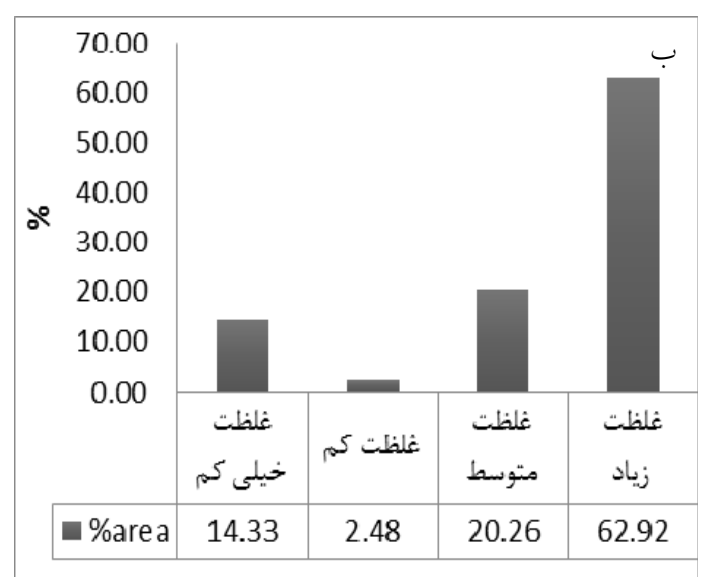

الف

شكل • ا. الف) نقشه تلفيقى لايه هاى مختلف كيفى دشت خرمآباد و ب) نمودار درصد غلظتهاى مختلف دشت

نسبت به ساير مناطق است. نتايج بررسى منسابع از نظر سـختى

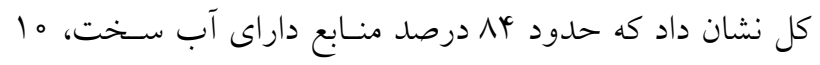
درصـد داراى آب كـاملاً سـخت و V درصــد داراى آب نسـبتاً سخت هستند. بهطور كلى بررسى شـاخص اشـباع لانزيسر نشـان مسىدهـد

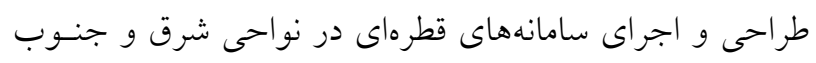
شرق محدوديتى وجود ندارد اما بـا حركـت بـهسمت نـواحى غربى بهدليل بالا بودن شاخص LSI، محدوديتهايى در اجراى سامانههاى قطرهاى و جود دارد. از جمله ايسن محسدوديتهــا در عمليات اصلاحى مانند استفاده از اسـيد و تغيــرات دمـا اسـت.

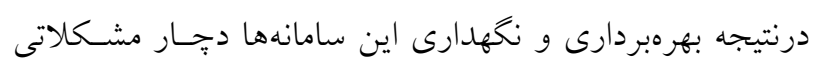

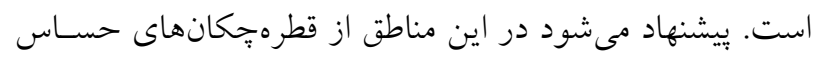
به كرفتكى استفاده نشود. درنهايت بررسى وضعيت كلى دشـت از نظر غلظت مشخصههاى كيفى مؤثر در بيادهسازى سامانهاى قطرهاى نشان داد كه حدود سو درصد دشت داراى غلظـت بـالا

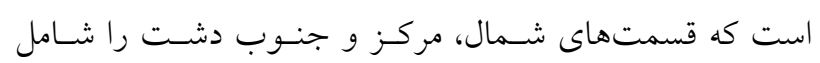
مىشود. با توجه به اينكه استان لرستان يكى از قطبهاى بخش

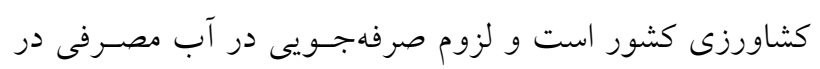

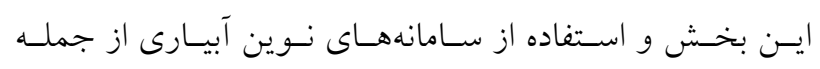

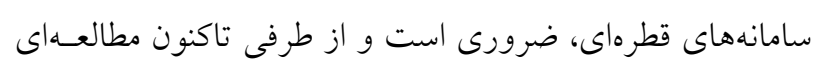

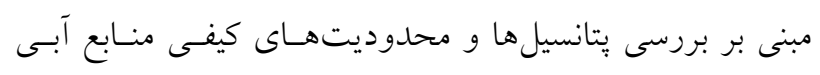

بوده و نشاندهنده يتانسيل گرفتخى قطرهجـــان در ايسن ناحيـه است. در ادامه بررسىها، اقدام به تلفيق نقشههاى يهنهبنـدى شـده تمام شاخصهاى كيفى مؤثر بر كرفتخى قطرهجِكـان شـد. ايسن

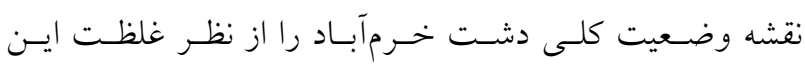
شاخص ها نشان مىدهد (شكل • إ- الف). با توجه به اين نقشه مشخص شد كه كمترين غلظت مشخصات كيفى دشت خرمآباد در غرب و بيشترين آن در نـواحى شـمالى، مركـزى و جنـوبى دشت گسترش يافته است. نمودار شكل ( إ- ب) نشـاندهنده درصد غلظت هاى خيلى كم، كم، متوسط و زياد كيفيـت منـابع

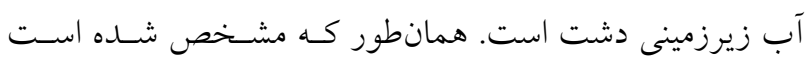
YT/AT درصد از وسعت دشت تحت غلظت زياد قرار دارد.

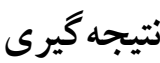

در اين يززوهش بعد از نرمالسـازى دادههـا از روش درونيـابى يُ

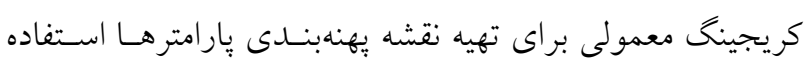
شد. نتايج حاصل از اين بزّوهش نشان داد كه ميزان يارامترهـاى كيفى مؤثر در گرفتخى قطرهجهانها داراى بر اكندگى زيـادى در

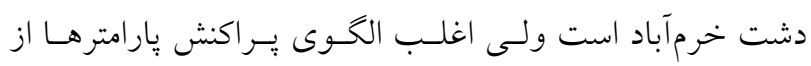
الخوى مشخصى تبعيت مى كنند. بهطورى كـه نـواحى شـمال و

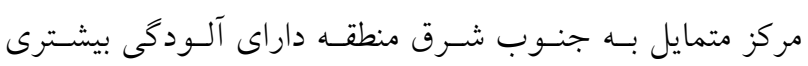




$$
\begin{aligned}
& \text { براى اجر ایى اين سامانها در سطح استان انجام نشده است، اميد مديريتى و اجرايى اسـتفاده شـود و مطالعـاتى بيشـتى در ايسن }
\end{aligned}
$$

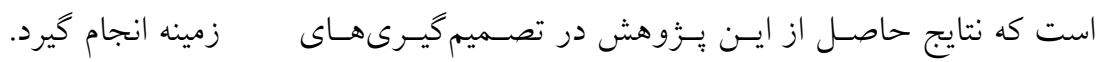

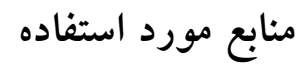

1. Ahmed, S. 2002. Groundwater monitoring network design: application of geostatistics with a few case studies from a granitic aquifer in a semi - arid region. American Journal 67: 1564-1571.

2. Alizadeh, A. 2009. Drop irrigation (principles and application). Second edition, Astan Quds Razavi Publishing House, Imam Reza University. (In Farsi).

3. Ansari Samani, F. 2012. Investigating the Effect of Phosphate Fertilizer on the Ecliptic of Several Droplets Available in the Iranian Market. MSc. Thesis. Department of Irrigation and Drainage, Faculty of Water Engineering. Shahid Chamran of Ahwaz University (In Farsi).

4. Azad, N., A. Rezaei Abajlu and G. Behmanesh. 2018. Locating areas prone to superficial and pressure irrigation systems using the fuzzy hierarchical process analysis process in Miandoab Plain. Journal of Irrigation Science and Engineering 41(4): 119-132 (In Farsi).

5. Azareh, A., M. R. Rahdari, F. Soleimani Sardo and J. R. Rafei Sharifabad. 2014. Assessment of the groundwater quality feasibility zones for irrigational purposes (Case study: Southwest part of Kerman province, IRAN). International Journal of Plant, Animal and Environmental Sciences 4(3): 544-551.

6. Baalousha, H. 2010. Assessment of a groundwaterquality monitoring network using vulnerability mapping and geostatistics: A case study fromHeretaunga Plains, New Zealand. Journal of Agricultural Water Management 97: 240-246.

7. Barberis, A. and Minelli, S. 2005. Land evaluation in the Shouyang county, Shanxi province, China. Agricultural Water Management, 95(2):133-142.

8. Bardossy, A. 2011. Interpolation of groundwater quality parameters with some values below the detection limit. Journal of Hydrology and Earth System Science. 15:2763-2775.

9. Bhat S., L. Motz, C. Pathka and L. Kuebler. 2012. Designing groundwater level monitoring network using geostatistical a case study and Central Florida U.S.A. Journal of World Environmental and Water Resources Congress. 48-58.

10. Dadrasi sabzevar, A. 2006. Quantitative and qualitative changes of groundwater resources and its role in destruction of land. The first regional conference on optimal utilization of water sources in Karoon and Zayandehrood, Shahrekord University. September 14th-15th, 2006 (in Farsi).

11. Ejlali, F., A. Asgari, M. Dehghani. 2016. Evaluation of groundwater quality in coastal lands of Mazandaran for agricultural use and application in drip irrigation system. Journal of Irrigation and Water Engineering 7(25): 2016 (In Farsi).

12. Farzam Nia, M. and S. Haghayeghi Moghadam. 2002. Investigating the effect of saline water on the eclipse of some droplets used in Iran. Journal of Irrigation Science and Engineering. 32: 15-25 (In Farsi).

13. Gaus, I., D. Kinniburgh, J. Talbot and R. Webster. 2003. Geostatistiscal analysis of arsenic concentration in groundwater in Bangladesh using disjunctive kriging. Environmental Geology 44: 939-948.

14. Ghaemizadeh, F. and S. Akhavan. 2014. The feasibility study of pressurized irrigation systems performance based on water quality (Case Study: Hamedan Province plains). Journal of Water and Soil Conservation 21(1): 65-83. (In Farsi.)

15. Gholami Sefidkoohi, M. A., M. Jafari, M. Zamani and S. Sadeghi. 2011. Zoning of groundwater quality indices and identification of areas with droplet blocking potential. Case study: Sari-Neka plain, In: Proceeding of the $11^{\text {th }}$ National Irrigation Workshop and Reduction of Evaporation. Kerman. Shahid Bahonar University (In Farsi).

16. Lalezari, R. and F. Ansari Samani 2012. Determination of vulnerable areas for the application of drip irrigation systems based on groundwater quality using ArcGIS. Journal of Water Research in Agriculture 28(2): 285-294. (In Farsi).

17. Morio, M., M. Finkel and E. Martac. 2010. Flow guided interpolation. A GIS-basedmethod to represent contaminant concentration distributions in groundwater. Environmental Modeling \& Software 25: 1769-1780.

18. Mousavi, S. F. 1996. Groundwater Pollution. Isfahan University of Technology. (In Farsi).

19. Nasrollahi, A. H. 2008. Investigating the effect of temperature on the discharge of several types of droplets in the Iranian market. MSc. Thesis. Faculty of Water Engineering, Shahid Chamran University of Ahvaz. (In Farsi).

20. Nazarizadeh, F., B. Ershadian, K. ZandVakili and M. Nouriemamzade'i. 2006. Investigating the variations in groundwater quality in Balarood plain in Khuzestan province. In: Proceeding of the First Regional Conference on Water Resources Utilization of Karun and Zayandehrood Basins (Opportunities and Challenges), Shahrekord, Shahrekord University. 
21. Ostovari, Y., H. Beigi Harcheegani and A. Davoodian. 2011. Evaluation, study of spatial variations and zoning of some water quality indicators for application in drainage irrigation design in Lordegan plain. Irrigation and Drainage Journal of Iran 2(5): 242-254 (In Farsi).

22. Qaredaghi, M. M., A. S Maroofpoor, Kh. Babaei and F. Mansouri. 2013. Potential of susceptible areas for using irrigation systems under pressure using GIS (Case study: Babakhan Irrigation and Drainage Network). Water and Soil Journal (Science and Technology) 27(6): 1111-1122. (In Farsi).

23. Ramzi, M., A. Khasheei Siyuki and A. Shahidi 2014. Determination of susceptible areas of drip irrigation using the hierarchical analysis process in South Khorasan province. Science and Technology of Agriculture and Natural Resources, Water and Soil Science 18(69): 227-235. (In Farsi).

24. Schultz, B. 2017. Agricultural Water Management and Food Security in a Sustainable Environment. In: Proceeding of the $13^{\text {th }}$ International Drainage Workshop of ICID, Ahwaz, Iran.

25. Smedema, L. K., S. Abdel-Dayem and W. J. Ochs. 1998. Drainage and agricultural development. Irrigation and Drainage Systems 14: 223-235.

26. Sun, Y., K. Shaozhong and L. Zhang. 2009. Comparison of interpolation methods for depth to groundwater and its temporal and spatial variations in the Minqin oasis of North West China. Environmental Modelling \& Software 24(10): 1163-1170.

27. Talebnejad, R. and A. R. Sepaskhah, 2015. Effect of different saline groundwater depths and irrigation water salinities on yield and water use of quinoa in lysimeter. Agricultural Water Management 148: 177-188.

28. Wilcox, L. V.1955. Classification and Use of Irrigation Water. USDA, Circular 969.Washington, DC. USA. 


\title{
Feasibility Study of Drip Irrigation Systems Regarding Groundwater Quality (A Case Study: Khorramabad Plain)
}

\author{
Y. Sabzevari and A. H. Nasrolahi ${ }^{*}$
}

(Received: December 24-2018 ; Accepted: June 17-2019)

\begin{abstract}
One of the ways to increase water productivity in agriculture is the use of new irrigation systems; for the precise design of these systems, water quality assessment is needed. The purpose of this study was to study the groundwater quality of Khorramabad plain for the implementation of drip irrigation systems. The qualitative indices of EC, SAR, TDS, TH, Na and $\mathrm{pH}$ were related to the statistical years 2006-2012. In this research, the data were normalized first and it was determined that the data were abnormal; so, the logarithmic method was used for normalization. To evaluate the groundwater quality of the area, land use methods were used. Among different methods, the ordinary kriging interpolation method with the least root mean square error for all parameters was used. Quality zoning maps showed that in the north and southwest, EC and SAR concentrations were in poor condition in terms of qualitative classification. TDS had a concentration of more than 4000 milligramrels, and Na had a concentration of more than 15 milligrams / ltr. In these areas, TH with the concentration of more than $730 \mathrm{mg} / \mathrm{l}$ had the highest contamination; in the central area of the plain, there was a higher risk of carbonate sediments. LSI rates in the western regions were more than one, which included about $12 \%$ of the plain; there were restrictions on the implementation of droplet systems in these areas. The best quality for implementing these systems was located in the south-east of the plain, covering $19 \%$ of the plain. Finally, the integrated map of qualitative characteristics showed that the maximum concentration of qualitative characteristics was located in the northern, central and southern regions, which included $62.29 \%$ of the plain area.
\end{abstract}

Keywords: Drip systems, Eclipse dropper, Langeir saturation index, Groundwater quality

1. Department of Water Engineering, Faculty of Agriculture and Natural Resources, Lorestan University, Lorestan, Iran.

*: Corresponding author: nasrolahi.a@lu.ac.ir 